\title{
Analysis on the Impact Effect on Marxism Education Mode for Network Education
}

\author{
LiYating \\ Nanchang Institute of Science \&Technology,Nanchang 330108,China
}

\begin{abstract}
Keywords: Network education; Marxism education; Education evaluation model; SWOT analysis
\end{abstract}
\begin{abstract}
On the basic idea of education as the guidance, this paper makes a comparison between network education and Marxism education. Network education is new education model under the contemporary science and technology, to establish the education evaluation model, the Marxism education under the new situation is analyzed by the SWOT, people conclude that the two kind of education modes appear with existence is reasonable, the education efficiency of network education has a great effect for the rational allocation of the Marxism education resources, and universities should adopt growth strategy, consolidating the education advantages, actively developing the continuing education, training and other network teaching modes, at the same time to expand diversified strategy, in order to have a competitive advantage of the fierce external conditions and complex internal conditions.
\end{abstract}

\section{Introduction}

In the 1990s, network education had began to rely the computer technology, internet technology and multimedia technology, which had a great development, the network education used network media and Marxism media as a tool in the implementation of the teaching process, its education produced the very big urge action in terms of openness, universal and diversified. Now, if you have an internet access to the computer, you can access the domestic and international network education website[1]. In the search engine, to type remote education or network education, you will get a URL, such as appropriate primary and secondary schools, Beijing Yucai middle school distance education network and so on.

The oversea statistical data shows that accepting the network educations have to close to $300 \%$ growth in the United States; through the network education to acquire the knowledge and skills, there are more than 7 millions, more than 65\% large firms are through network education to train employees[2]. Most American schools have established teaching and matching network curriculum, especially the higher education colleges, not only such, professional learning websites and forums have been rapid also development.

\section{Comparison of the two educational implementation modalities}

In the current higher education, curriculum arrangement and realization gradually toward the development of the science technology and the network, students in the dormitory or home will be able to complete the teaching tasks of the teachers layout, these tasks can be a course of study, and can also be experimental analysis. Not only that, the network educations have gradually extended to primary school and secondary school's classroom as well as extracurricular teaching process, the Marxism education builds the classroom as the center, teachers as leading, students as the object model has began to change, the students' role and status have changed in the network education. Marxism education under the impact of contemporary science technology has evolved, so the inherent idea of using Marxism education also should change. Compared with the Marxism education, network education is based on computer technology, internet technology and multimedia technology to launch the teaching activities, and the existing widely accepted Marxism education has many differences. Mainly performance is shown in Table 1. 
Table 1 Comparison of Marxism education and network education

\begin{tabular}{|c|c|}
\hline Marxism education & Network education \\
\hline Taking the classroom as center learning & No classroom location restrictions \\
\hline Teachers and students must be in the classroom & Teachers and students can be far apart \\
\hline All students in the fixed time to unify study & Students can choose the time \\
\hline All students synchronous learning & Students choose progress \\
\hline To form a fixed learning groups & Learning group \\
\hline Teachers guide as the center & Students their arrange \\
\hline Basic controlled by the teacher & Students autonomous control \\
\hline Students passive accept knowledge & $\begin{array}{l}\text { According to the demands of students } \\
\text { active learning knowledge }\end{array}$ \\
\hline $\begin{array}{l}\text { Verbal exchanges between teachers and } \\
\text { students }\end{array}$ & No communication \\
\hline Learning and life have real space & Virtual learning and living space \\
\hline The real scene causes teaching experience & $\begin{array}{l}\text { Virtual scene caused by teaching } \\
\text { experience }\end{array}$ \\
\hline $\begin{array}{l}\text { Activities rich between classes and } \\
\text { extracurricular }\end{array}$ & Having a study of imagination \\
\hline
\end{tabular}

From the comparison in Tab.1, it can be found that the teacher plays a major role of the guidance and control in the reality of the classroom education, the students takes the teacher as the center to accept knowledge, however teaching schedule flexibility is poor. In contrast, the network education has no real learning space and activities, no longer taking the teacher as the center, the students are required to have certain autonomy, which has a certain understanding for their knowledge structure, initiative to seek knowledge, and rational arrangement progress, its disadvantage is the lack of face-to-face communication, and its environment is single.

\section{Education evaluation model and its implementation}

The establishment of education evaluation model. Education evaluation has the definition of three aspects, including the value judgment, evaluation development, reference standard. Compared with Marxism education, network education has distinct characteristics, such as teaching, learning in spatial separation, which require that learners need to control, the last section has been discussed in details. How to point of view from mathematical model, to analyze the advantages and disadvantages of the two modes, which is the key content of this paper, to construct education evaluation model in this section.

Based on the characteristics of network education and Marxism education evaluation, to establish the education evaluation models as shown in Figure 1.

Teaching evaluation system is the organic combination of teacher, student, teaching material (material), teaching support system (foundation) and teaching service system (service), using mathematical expression for[3]:

TES $=\{$ Teacher, Student, Material, Foundation, Service $\}$

(1)

In order to quantitatively analyze the convenience, to constitute the subset weight of teaching evaluation system that can get score index of evaluation system[4]:

TESscore $=0.3$ Teacher +0.3 Student +0.15 Material

(2)

$$
+0.15 \text { Foundation }+0.1 \text { Service }
$$

In formula (2), TESscore is expressed as model score; $0.3,0.3,0.15,0.15$ and 0.1 are respectively expressed as weight distribution.

The quality index can be expressed as[5]: 


$$
\text { Indicator }=\frac{\text { Sample }(\text { TESscore })-\text { Total }(\text { TESscore })}{\text { total }(\text { TESscore })}
$$

(3)

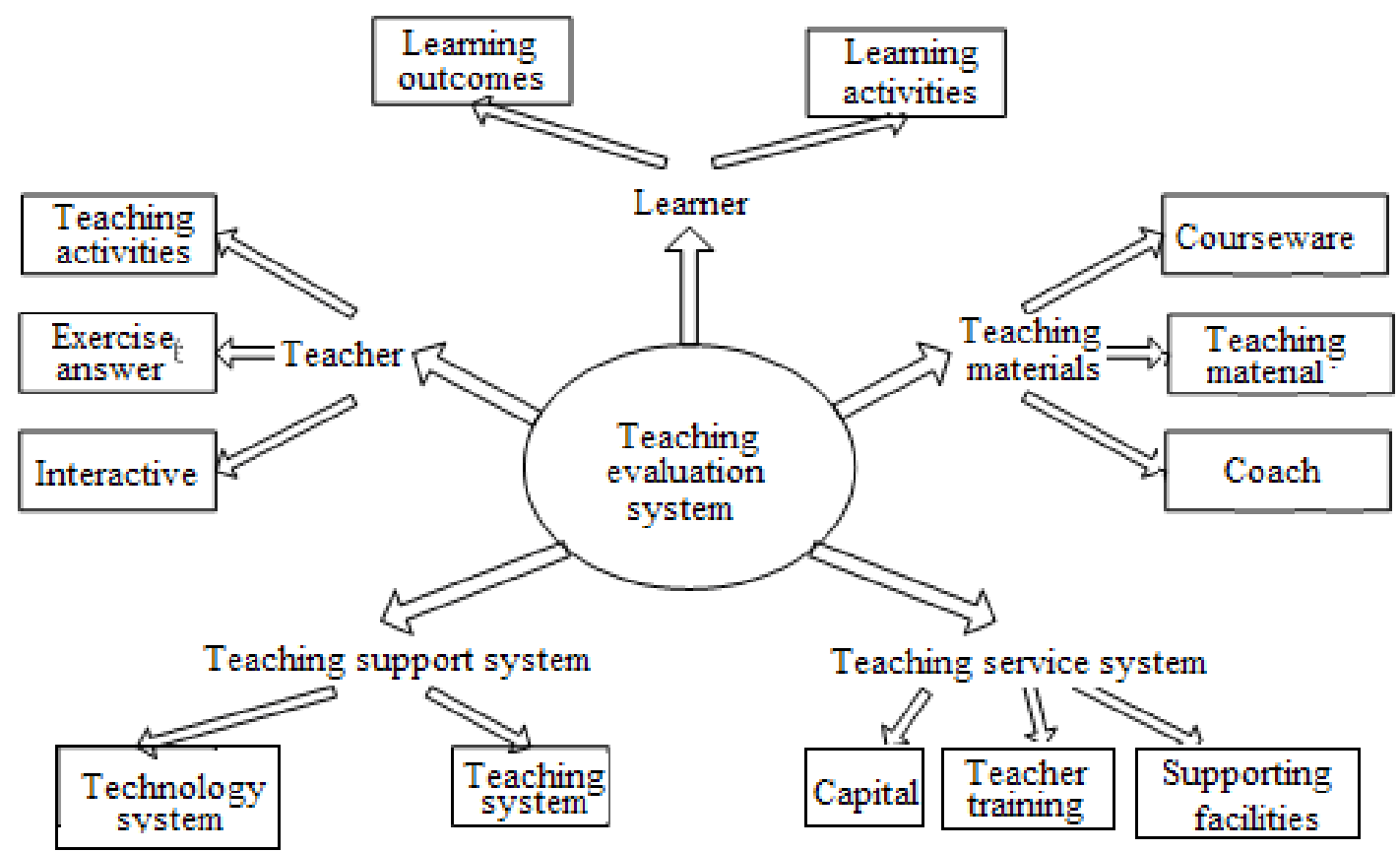

Fig.1 Education evaluation model

Evaluation method. The evaluation model is established, to select the appropriate evaluation methods that can be divided into two evaluation methods, including summative and formative. Summative assessment is a result of method, which carries out implementation result of the education evaluation in a certain period, this purpose implements the teaching results of the evaluation, to assess for the final score and check the teaching effect. Marxism education generally uses the summative evaluation, which will affect teachers' professional evaluation and graduate students.

Evaluation factors. Education evaluation should be comprehensive and meticulous, its main contents include the learner's rich knowledge, to build evolution factor. From the macro perspective, it is the overall evaluation of education system; from microcosmic angle, it mainly evaluates teachers' teaching activities and learning efficiency. Compared with Marxism education, learners' knowledge accumulation does not directly depend on teachers in network education, but also chooses to study progress and learning content[6]. Evaluation factors involve three aspects: for learning evaluation, the object of education is learners, its evaluation is the main content; for teachers evaluation, teachers are the main perpetrators of teaching activities, its teaching ability directly affects the effectiveness of education; for the evaluation of teaching content, it is not the same with Marxism education, and network education is quite broad, which is not confined to the network courseware, it also includes a variety of network learning materials, at the same time, generally using formative assessment to evaluate the teaching content.

\section{The SWOT analysis of the impact effect on network education for the Marxism education}

SWOT analysis principle. SWOT analysis is a kind of trend analysis, which is able to accurate analysis of a company or industry development. Among them, the analysis framework of SWOT includes the advantage, disadvantage, internal and external circumstance analysis, portfolio analysis, mathematical tools that have the chart type, matrix type and quadrant type[7].

The current development of network education. In 2009 2011, the number of Marxism education and network education's enrollment and graduation statistics are shown in Table 2. 
Tab.2 The scale of Marxism education and online education (Unite: million)

\begin{tabular}{|c|l|c|c|c|}
\hline Years & \multicolumn{1}{|c|}{ Categories } & $\begin{array}{l}\text { Number of } \\
\text { graduates }\end{array}$ & Enrollment & $\begin{array}{l}\text { Number of } \\
\text { students }\end{array}$ \\
\hline \multirow{2}{*}{2009} & $\begin{array}{l}\text { Marxism adult undergraduate } \\
\text { /specialist }\end{array}$ & 162.55 & 176.32 & 423.35 \\
\cline { 2 - 5 } & $\begin{array}{l}\text { Network education } \\
\text { undergraduates }\end{array}$ & 93.45 & 147.67 & 409.23 \\
\hline \multirow{2}{*}{2010} & $\begin{array}{l}\text { Marxism adult undergraduate } \\
\text { /specialist }\end{array}$ & 164.25 & 170.32 & 456.43 \\
\cline { 2 - 5 } & $\begin{array}{l}\text { Network education } \\
\text { undergraduates/ specialist }\end{array}$ & 99.75 & 159.76 & 419.50 \\
\hline \multirow{2}{*}{2011} & $\begin{array}{l}\text { Marxism adult undergraduate } \\
\text { /specialist }\end{array}$ & 165.55 & 169.32 & 476.19 \\
\cline { 2 - 5 } & $\begin{array}{l}\text { Network education } \\
\text { undergraduates/ specialist }\end{array}$ & 108.45 & 163.67 & 439.47 \\
\hline
\end{tabular}

In Table 2, it can be found that the number of college graduates is only $57 \%$ of the Marxism adult graduates in 2009; however the later two years have gradually increased, reducing the gap between them. The proportion has increased to 65\% in 2011, and the network education admissions have gradually strengthened, enrollment size is close to the Marxism education. Thus, it can be seen that the Marxism adult education is still dominant at this stage, and the development situation of network education has been a larger scale, the Marxism university continuing education has produced certain effect.

The SWOT analysis based on evaluation model .With the quick development of network education, the Marxism education has produced the important influence in Marxism education, however the Marxism education still has its irreplaceable position, the following will be based on SWOT framework analysis principle, the Marxism education is analyzes the impact of network education, the analysis of main contents includethe following aspect[8].

Advantages.(1) Intangible assets advantage

The Marxism college has a strong force of teachers, a wide range of disciplines and a long history of accumulation, these advantages are network education that is unable to compare, learners get the gold content of degree certificate that is higher, which has been widely accepted by the society.

(2) Human resource advantages

The Marxism universities have a full-time staff, their teaching and research standards are relatively high, data shows that the teachers have 1.343 million in 2011; graduate student teacher ratio has increased from 29\% in 2000 to $43 \%$. Moreover, universities have gathered a large number of high level talents. At present, the academician of national university is accounted for the total number of $47 \%$ and $39 \%$, the human resources rational allocation will form the unique advantages of Marxism education.

(3) Customer loyalty advantage

The college has a long brand strength, good public reputation and customer loyalty.

Disadvantages. (1) Organizational system rigidity

The education model and the concept of Marxism university are relatively old, the reform implementation degree of existing management system is not high, the sensitivity is low, the operation is lack of the market experience, and curriculum is lower with matching the rapid development of the social demands.

(2) Lack of funds

The Marxism university has extended network education model that needs to be equipped with hardware support and website construction, universities need to expand cooperation mode, promoting the integration of educational resources, to achieve resource sharing.

Opportunities. (1) Favorable policy environment 
In the twelfth five-year plan, it emphasizes the development of network education, to construct the importance of lifelong learning system. At the same time, college admission is high, the aptitude advantage of Marxism college is particularly precious, and it has monopolistic advantage.

(2) Favorable economic and population environment

Our country is in economic development and a crucial period of social transition, the need of talent are large quantity, especially it is adapt to the new era of high-quality personnel, and the continuing education of various forms is adapted to the needs of reality. Marxism education should draw the flexibility characteristics of network education, to meet the demands of social diversification talents,

Threats. Threats are from the external industry, using Potter model to analyze as shown in Figure 2. The external competition ability includes: potential competitors to enter the market capacity; supplier cost control ability; alternative to the self replacement ability; bargaining power of the purchaser, the five kinds of power represent a form of competition in the industry.

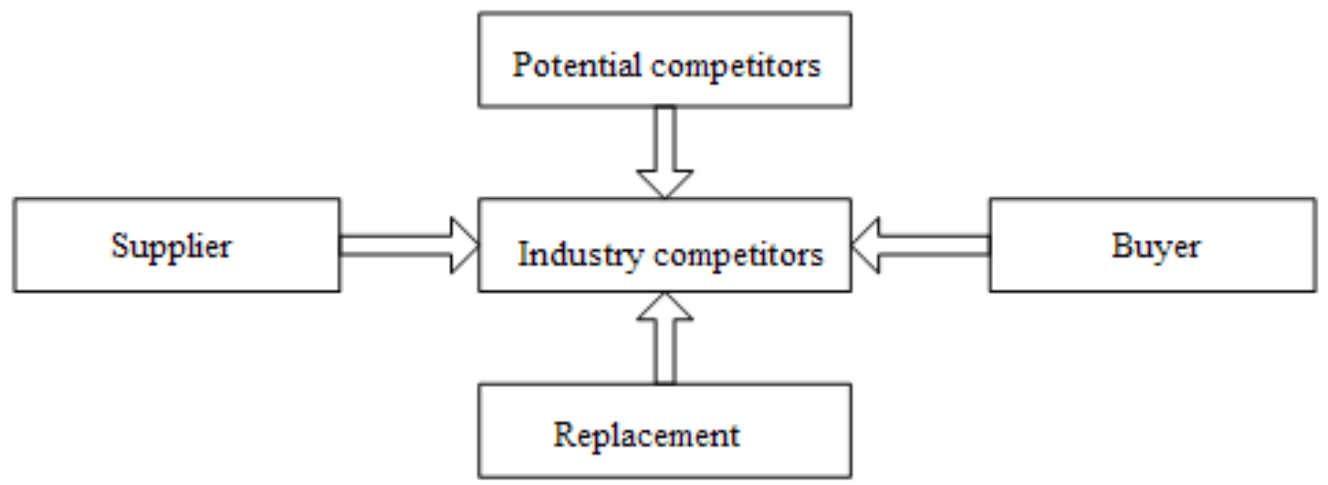

Fig 2 Potter's five force model

\section{Marxism education strategies}

Facing the above combinations of advantages and disadvantages, opportunities and threats, the Marxism universities should take what kind of strategies, it can be from SWOT matrix to set out and analyze. SWOT matrix analysis is shown in Table 3.

Tab.3 SWOT matrix analysis

\begin{tabular}{|c|c|c|}
\hline & Advantages & Disadvantages \\
\hline Opportunities & SO growth strategy & WO reverse strategy \\
\hline Threats & $\begin{array}{c}\text { STA variety of business } \\
\text { strategy }\end{array}$ & $\begin{array}{c}\text { WT defensive } \\
\text { strategy }\end{array}$ \\
\hline
\end{tabular}

Growth strategy (SO). When the internal advantages are consistent with external opportunities, growth strategy is used. In this case, the Marxism universities should keep teacher advantages and brand strength, to strengthen the advantage of network continuing education field, at the same time to seize opportunity in the period of social transformation, the development of network education, to meet the diversified needs of social learning, the integration of existing resource advantage, and the aid of the network to establish the industry competitive advantages.

Reverse strategy (WO).When the internal advantage and external opportunities are not consistent, it can be taken to reverse strategy, through the external opportunities to compensate for internal weaknesses. In the face of strong external opportunities, colleges should be deepen reform, continuing to explore new ways to achieve separation of teaching and learning, creating more sensitive to innovative mechanism, which can carry out cooperation with enterprises to promote internal disadvantage into advantage.

Kinds of management strategy (ST).In the face of opening education and Marxism education, they have the threat of being replaced, colleges should make good use of oneself advantage. One should strengthen brand teaching advantage, and reversing organization management system disadvantage; on the other hand also must strengthen the expansion, using the differentiation, 
diversification strategy, it mainly emphasizes the Marxism educational rigor, enhancing brand value.

\section{Conclusion}

According to the basic of education thought as a guide, compared with the implementation characteristics of Marxism education, the network education is the new education model of contemporary science technology, to establishing the education evaluation model, and then the Marxism education under the new situation carries out the SWOT analysis, it can be concluded that the emergence and existence of these two educational models are reasonable, the network education is the rational allocation for the resources of Marxism education, it has also a great effect for the gradual improvement of education efficiency. At the same time, the network education should also learn from the Marxism education's success, two is the mutual competition, mutual promotion and mutual development.

\section{References}

[1] Dong Junmin. Research on the relationship of modern distance education teaching and learning [J]. Journal of higher correspondence education, 2010 (3): 45-46.

[2] Yu Le, Huang Anxin. Construction of modern distance education on occupation technology teaching model [J]. Research on modern distance education, 2009 (6): 58-59.

[3] Wu Zhenhua. Research on American network education information resources development and present situation [D], Shanghai: Shanghai normal university, 2009: 1-15.

[4] Wang Xiaoling, Teaching evaluation theory and technology [M], Shanghai: Shanghai education press, 2009: 121-135.

[5] Zhang Xiaohong. Fusion of distance education and modern information technology [J]. Neijiang science, 2010 (10): 49-50.

[6] Mo Zai, Gao Jingguang. Comparison research on modern distance education and Marxism education teaching pattern [J]. Journal of Guangdong technology university (social science edition), 2009 (S1): 34-35.

[7] Zhang Yaoxue. Impact of the network on Marxism university mode [J]. Chinese higher education, 2009 (21): 54-55.

[8] Guo Songqin. Analysis of the relationship between teacher and student in network education and Marxism education mode [J]. Health occupation education, 2009 (24): 76-78. 